\title{
113. デジタルシンチカメラの性能管理
}

Quality Contorol of Digital Scintilation Camera
神奈川県记がんセンター
○石井幸弘
伊勢 俊秀
奥村 貴聡
東芝メディカル東京サービス(株)
Yukihiro Ishi i Toshihide Ise Tkatoshi okumura 福田 敏男
Toshio Fukuda

【目的】デジタルシンチカメラ(東芝(GCA90B W2)O)設置より5年、その 間0性能変化を視野均一性について解析する。

【方法】週1回(ユーザによる)、およひ定期点検時(3 4力月毎に1回サ ビスマンによる)に收集した5年間の視野均一性を、点検時、点検 後4週、8週、12週、定期点検直前、および設置後の年数によりどの ように変動するか検討した。

本装置O)基本性能は、検出器固有分解能FWH 4.5mm，視野均一性、 5\%以内、視野直線性 $0.5 \%$ 以内。また、検出器系の点検方法は、LV 電源チェック、PYT調整、位置信号系調整扰よひ確認、エネルギー 補正打よび直線性補正デー夕の収集、最後に基本性能の確認にて 終了。

【まとめ】エネルギーと值線性補正機能を有するデジタルシンチカメ ラの視野均一性は、エネルギーと直線性補正デー夕(以下補正デー 夕）の収集を行わないと経時的に少化することは、44回総会で報 告したとおり約11週 13週を越えるとメーカー仕様の5\%を越え、 その後も経時的に劣化する。(図1)

しかし、定期点検時に補正データを収集することにより視野均 性は3\%台になる。

また、定期点検時に、補证デー夕を収集後に測定した視野均一性(C FOV)は、平均3.7-0.4\%(3.8:0.4\%)、定期点検上り4週後では、4.20. $5 \%(4.20 .8 \%) 、 8$ 週後4. $50.7 \%(4.20 .8 \%) 、 12$ 週後4.5 0.6\%(4.30.

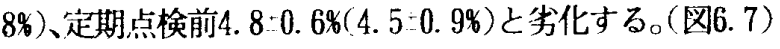

( )内はDET 2

設置後の視野均一性の経年変化は、4.2:0.4\% 4.4:0.4\%(3.9:0.4 4.10.4\%)で、ほぼメ一力仕様を満足していることが分かる。 (図2 5)

今回、エネルギーと直線性補正機能を有するデジタルシンチカメ ラの性能変化を視野均一性について検討した結果、約11週 13週 を越えない期間每に定期点検を行い補正デー夕の収集を行うこ とにより、本装置は設置時の性能を保持していることが確認でき た。

\section{【参考文献】}

中村 豊

他 : デジタルシンチカメラシステムの性能管理

日放技学誌 $44(8), 1169$ ，(1988）
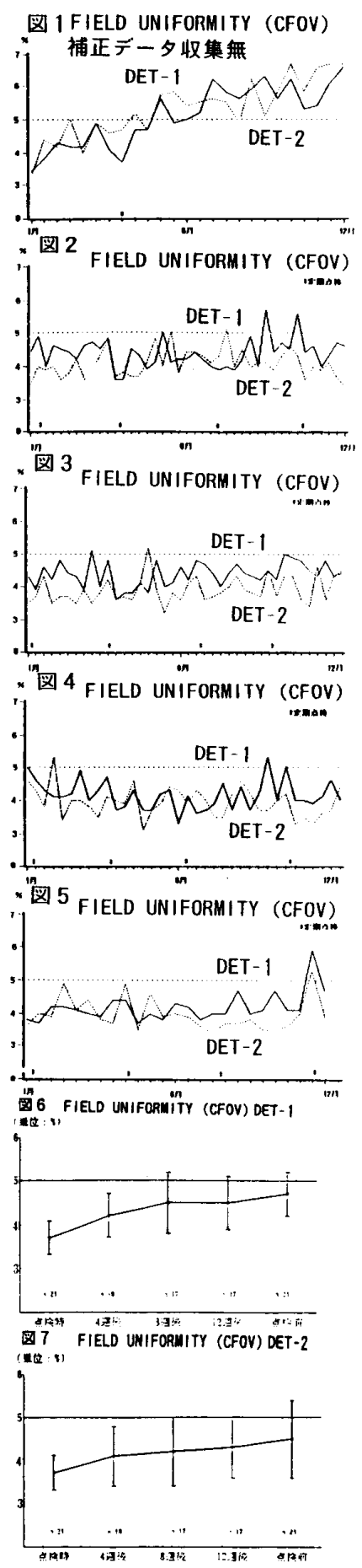